\title{
Phytochemical analysis and botanical origin of Apis mellifera bee pollen from the municipality of Canavieiras, Bahia State, Brazil
}

\author{
Análise fitoquímica e origem botânica de uma amostra de pólen apícola \\ do município de Canavieiras, Estado da Bahia, Brasil
}

\author{
Giuseppina Negri ${ }^{\text {* }}$ (), Lidia Maria Ruv Carelli Barreto², Fábia Lugli Sper ${ }^{3}$, Claudemir de Carvalho³, \\ Maria da Graça Ribeiro Campos ${ }^{4}$ \\ 1 Universidade Federal de São Paulo (UNIFESP), Departamento de Medicina Preventiva, Centro Brasileiro de Informações sobre Drogas Psicotrópicas, \\ São Paulo/SP - Brasil \\ 2 Universidade de Taubaté (UNITAU), Taubaté/SP - Brasil \\ ${ }^{3}$ Faculdade de Pindamonhangaba (FUNVIC), Pindamonhangaba/SP - Brasil \\ ${ }^{4}$ Universidade de Coimbra, Faculdade de Farmácia, Centro de Química de Coimbra /Polo III, Azinhaga de Santa Comba, Coimbra - Portugal
}

\section{*Corresponding Author}

Giuseppina Negri, Universidade Federal de São Paulo (UNIFESP), Centro Brasileiro de Informações sobre Drogas Psicotrópicas, Departamento de Medicina Preventiva, Rua Botucatu, 740, Vila Clementino, São Paulo/SP - Brasil, e-mail: gnegri@terra.com.br

Cite as: Phytochemical analysis and botanical origin of Apis mellifera bee pollen from the municipality of Canavieiras, Bahia State, Brazil. Braz. J. Food Technol., v. 21, e2016176, 2018.

Received: Dec. 04, 2016; Accepted: Sept. 22, 2017

\section{Abstract}

An Apis mellifera bee pollen sample from Bahia state in Brazil was studied to evaluate its botanical origin and phytochemical composition. The bee pollen sample was collected in the municipality of Canavieiras, in an area with a very high predominance of Cocos nucifera $L$ (Aracaceae), which was identified as the major taxon (99\%), thus being the possible botanical origin of this pollen. The main constituents found in the non-polar extract analysed by GC-EI-MS were saturated fatty acids and long chain esters, together with phytosterols such as ergosta-5,24(28)-dien-3-ol, campesterol and sitosterol, detected in smaller quantities. Flavonoid glycosides, as well as hydroxycinnamic acid amide derivatives were detected in the polar extract analysed by HPLC-ESI-MS/MS. The presence of flavonoid glycosides, hydroxycinnamic acid amide derivatives, fatty acids and phytosterols have been reported in many bee pollen taxa. To the best of the authors' knowledge, this is the first study of the chemical composition of bee pollen from C. nucifera, which is cultivated for its coconut fruit.

Keywords: Apis mellifera bee pollen; Cocos nucifera; Fatty acids; Flavonoid glycosides; Phytosterols.

\section{Resumo}

Uma amostra de pólen apícola de abelhas Apis mellifera, coletada no Estado da Bahia, foi estudada com o objetivo de identificar a sua origem botânica e a sua composição química. A amostra de pólen apícola foi coletada no município de Canavieiras, em uma área onde ocorre a predominância de Cocos nucifera L (Aracaceae), a qual foi identificada como o maior táxon (99\%) desta amostra, podendo ser considerada a origem botânica deste pólen. Os principais constituintes encontrados no extrato não polar, que foi analisado por CG-EM, foram ácidos graxos saturados e ésteres de cadeia longa, além de esteroides, tais como ergosta-5,24(28)-dieno-3-ol, campesterol e sitosterol, os quais foram detectados em menor quantidade. Flavonoides glicosídeos e amidas derivadas do ácido hidroxicinâmico foram encontrados no extrato polar, que foi analisado por HPLC-ESI-MS/MS. A presença de flavonoides glicosídeos e amidas derivadas do ácido hidroxicinâmico, ácidos graxos e esteroides foi reportada em muitas amostras de pólen, por vários autores. Este é o primeiro estudo que avalia a composição química de uma amostra de pólen originada de Cocos nucifera L, uma planta que é cultivada para a produção do coco.

Palavras-chave: Pólen apícola; Cocos nucifera; Ácidos graxos; Flavonoides glicosídeos; Esteroides. 


\section{Introduction}

Bee pollen is an apicultural product of commercial interest due to its high nutritional value. As a source of energy and proteins for human nutrition, it is used to produce dietary supplements in the form of tablets, capsules and granulates. Bee pollen extracts may also be prepared in the form of alcohol and aqueous extracts (FEÁS et al., 2012; KOMOSINSKA-VASSEV et al., 2015; BÁRBARA et al., 2015; ZHOU et al., 2015). Pollen is the male gametophyte of flowers. Bee pollen is pollen collected by the honey bee Apis mellifera for the purpose of feeding its larvae in the early stages of development (CAMPOS et al., 2008). As such, bee pollen is a mixture of materials from different plant species containing pollen mixed with nectar and bee secretions that bind the grains together (FEÁS et al., 2012; KOMOSINSKA-VASSEV et al., 2015; BÁRBARA et al., 2015; ZHOU et al., 2015). Bees collect pollen from a large number of taxa, but only a few of these contribute significantly to their nutritional requirements (LIOLIOS et al., 2015).

The chemical composition of bee pollen depends largely on the plant source and geographical origin, as well as other factors such as climate, soil type, and bee species (KOMOSINSKA-VASSEV et al., 2015; BÁRBARA et al., 2015). Approximately 250 substances, including amino acids, lipids (triglycerides, phospholipids and fatty acids), phenolic compounds, vitamins, and flavonoid glycosides have been detected in bee pollen (KOMOSINSKA-VASSEV et al., 2015; BÁRBARA et al., 2015; ZHOU et al., 2015). Bee pollen also contains macronutrients (calcium, phosphorus, magnesium, sodium and potassium) and micronutrients (iron, copper, zinc, manganese, silicon and selenium) (KOMOSINSKA-VASSEV et al., 2015; ZHOU et al., 2015).

The therapeutic properties of bee pollen, such as antioxidant and antimicrobial activities, amongst other properties, have been attributed to the presence of flavonoids, phenolic acids and hydroxycinnamic acid amides (GABRIELE et al., 2015; CHEN et al., 2015; KOMOSINSKA-VASSEV et al., 2015; FEÁS et al., 2012).

Some authors have reported the presence of rutin as one of the flavonoids present in pollen. Markham and Campos (1996) pointed out that when identification was carried out using the correct procedures with NMR, the linkage between rhamnose and glucose was $1 \leftrightarrow 2$ (neohesperidose), and not $1 \leftrightarrow 6$ (rutinoside), as is evident in the rutin sugar moiety. From a nutritional standpoint this is not relevant, but for taxonomic and biosynthesis studies, it is a very important issue. This preponderance of flavonol 3-O-di- and tri-glycosides containing a 1,2 interglycosidic linkage is unlikely to be coincidence, especially as it encompasses such a wide range of taxa (MARKHAM; CAMPOS, 1996; CAMPOS et al., 2003; CAMPOS; MARKHAM, 2007).
Triacylated spermidines or HCA are predominant in pollen from oak species and in Arabidopsis thaliana pollen (HANDRICK et al., 2010), while diacylated spermidine conjugates are found in pollen from Betulaceae and Juglandaceae species (FELLENBERG et al., 2009).

The focus of this study was on the physicochemical and phytochemical analyses of Apis mellifera bee pollen collected in the municipality of Canavieiras, Bahia StateBrazil.

\section{Material and methods}

The bee pollen analysed in the current study was collected in an area with a high predominance of Cocos nucifera L. (Arecaceae) in the municipality of Canavieiras,

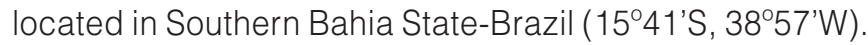
The area is comprised of a mangrove, large tracts of Atlantic forest, and also "restinga" and dune vegetation, with a predominance of palms such as Cocos nucifera L. (Arecaceae). C. nucifera blooms throughout the year, peaking between January and April (LORENZI, 2002). Other plant species found in this ecosystem are important polliniferous and nectariferous plant species. They also bloom throughout the year but peak between August and September (DÓREA et al., 2010). C. nucifera is traditionally cultivated for its coconut fruit.

\subsection{Palynological analysis: identification of pollen taxa in the sample}

The sample was prepared by the acetolysis method (ERDTMAN, 1960), and for the quantitative analysis, 1,500 pollen grain samples were used (VERGERON, 1964). The relative and average abundances and relative frequency of the pollen grains in the samples were calculated according to Louveaux et al. (1978).

\subsection{Bee pollen sample}

The Apis mellifera bee pollen sample (Natuflora P-433) was provided by a consumer of the product. The bee pollen (200 g) was manually cleaned and oven-dried at $45^{\circ} \mathrm{C}$ to constant weight $(160 \mathrm{~g})$. It was then ground to pass through a size 30 mesh and stored in sealed glass vials at $5^{\circ} \mathrm{C}$.

\subsection{Physicochemical analyses}

The physicochemical analyses, such as the moisture, protein, lipids, ash and sugar contents were carried out using previously described methodologies.

In order to determine the moisture content, $2.0 \mathrm{~g}$ of bee pollen was dried at $105^{\circ} \mathrm{C}$ to constant weight to determine the water loss. The ash content was determined after incineration at $560^{\circ} \mathrm{C}$. The $\mathrm{pH}$ was measured after mixing $2.0 \mathrm{~g}$ of bee pollen with $5 \mathrm{ml}$ of milli-Q 
Phytochemical analysis and botanical origin of Apis mellifera bee pollen from the municipality of Canavieiras, Bahia State, Brazil

Negri, G. et al.

water (BÁRBARA et al., 2015). The protein content was determined using the standard determination of $\% \mathrm{~N}$ by the Kjeldahl method, with a conversion factor of 6.25 or 5.6 (CAMPOS et al., 2008). The total sugars were determined using the dinitrosalicylic acid method (BÁRBARA et al., 2015).

The lipid content was determined by extraction with dichloromethane using a soxhlet reflux apparatus, as outlined by Archini et al. (2006). The total acidity was determined using $2.0 \mathrm{~g}$ of bee pollen mixed with $5.0 \mathrm{~mL}$ milli-Q water and titrating with $0.1 \mathrm{M} \mathrm{NaOH} 0.1 \mathrm{M}$ to a $\mathrm{pH}$ of 8.5 (BÁRBARA et al., 2015).

\subsection{Preparation of the non-polar and polar Apis mellifera bee pollen extracts}

The pollen sample was powdered using liquid nitrogen with a mortar and pestle. Two extracts were prepared using this pollen sample: a non-polar extract using dichloromethane as the solvent; and a polar extract using a methanol/water mixture $(1: 1)$ as the solvent. The non-polar extract was prepared with $200 \mathrm{mg}$ aliquots of bee pollen and dichloromethane $(30 \mathrm{~mL})$ as the solvent, refluxing in a Soxhlet, apparatus for 3 hours at approximately $60^{\circ} \mathrm{C}$. The yield was $30 \mathrm{mg}$ of dichloromethane (non-polar) extract.

The polar extract was prepared with $200 \mathrm{mg}$ of bee pollen macerated in methanol/water (30 mL, 1:1) for 24 hours. The yield was $70 \mathrm{mg}$ of hydromethanolic (polar) extract. The dry extracts were maintained in amber flasks at $5^{\circ} \mathrm{C}$

\subsection{Analyses of the non-polar extract using Fourier Transform Infrared spectrometry (FTIR)}

The basic functional groups of the Apis mellifera bee pollen non-polar extract were analysed qualitatively by the Fourier Transform Infrared method (ZIMMERMANN; KOHLER, 2014; HUCK, 2015). The FT-IR spectrum was recorded using a Bomem spectrometer at room temperature (ca. $25^{\circ} \mathrm{C}$ ). Triplicate $2 \mathrm{mg}$ aliquots of the non-polar extract were homogenised with $100 \mathrm{mg}$ of $\mathrm{KBr}$ powder and the mixture pressed into a thin pellet using a manual hydraulic press. The spectrum was obtained from the average of 32 scans in the range from 4000 to $400 \mathrm{~cm}^{-1}$, with $5 \mathrm{~cm}^{-1}$ spectrum resolution and normalization at $1030 \mathrm{~cm}^{-1}$. The influences of $\mathrm{H}_{2} \mathrm{O}$ and $\mathrm{CO}_{2}$ were subtracted automatically by the instrument.

\subsection{Analysis of the non-polar extract using GC-EI-MS}

A $1 \mu \mathrm{L}$ aliquot of the non-polar extract, at a concentration of $3.33 \mathrm{mg} / \mathrm{ml}$, was analysed using the Shimadzu GCMS-QP505A gas chromatograph equipped with a DB- 5 HT fused silica capillary column BPX5 (non-polar $5 \%$ phenyl polysilphenylene) (30 m x $0.25 \mathrm{~mm}$ internal diameter $\times 0.25 \mu \mathrm{m}$ film thickness) and an ion-trap mass detector.

Mass spectra were acquired in the electron-impact (El) mode with an ionization voltage of $70 \mathrm{eV}$, between $\mathrm{m} / \mathrm{z} 50$ and 600 . The oven was programmed as follows: the initial temperature of $100{ }^{\circ} \mathrm{C}$ was maintained for $5 \mathrm{~min}$ and then increased to $320^{\circ} \mathrm{C}$ at the rate of $6{ }^{\circ} \mathrm{C} / \mathrm{min}$. The final temperature was maintained for $10 \mathrm{~min}$. Helium was used as the carrier gas at a flow rate of $2.1 \mathrm{~mL} / \mathrm{min}$, ion source temperature of $300^{\circ} \mathrm{C}$; interface temperature of $300{ }^{\circ} \mathrm{C}$; and scan speed of 2 scans s${ }^{-1}$.

Identification of the constituents, whenever possible, was carried out using fatty acid, hydrocarbon and steroid standards. The mass spectral data were also compared with the following computerized MS-databases: Wiley 275, Wiley 229 and the NIST 21 library at 95\% confidence, and with data in the literature (KAFFARNIK et al., 2014; OLVERA-GARCIA et al., 2015). The concentrations of the constituents (relative contents) were obtained by calculating the percentage peak areas on the GC chromatograms.

\subsection{Analyses of the polar extract using RPHPLC-DAD-ESI-MS/MS}

Rutin (PubChem CID:5280805, Quercetin-3-ORhamnosyl-(1-2)Glucosyl), Quercetrin (PubChemCID:5280459, Quercetin - 3-O - L-rhamnoside), Quercetin (PubChem CID:5280343), and Isorhamnetin (PubChem CID:5281654, 3'-Methoxyquercetin) were obtained from Sigma-Aldrich Chemical CO. (St. Louis, MO, USA) and used as the standards. The RPHPLC-DAD-ESI-MS/MS analysis was carried out using the Shimadzu DADSPD-M10AVP5 system equipped with a photodiode array detector coupled to Amazon Speed ETD, Bruker Daltonics (Shimadzu Corporation Kyoto, Japan).

The mass detector was a quadrupole ion trap equipped with an atmospheric pressure ionization source with an electrospray ionization interface, which was operated in the full scan MS/MS mode. All the operations, acquisitions and data analyses were controlled by the Shimadzu CBM-20A software. The polar extract $(3.33 \mathrm{mg} / \mathrm{ml})$ was filtered through a $0.45 \mu \mathrm{m}$ PFTE filter and a 30.0- $\mu \mathrm{L}$ aliquot of the filtrate injected into the HPLC system. Spectral UV data was collected in the range from 240 to $400 \mathrm{~nm}$, and the chromatograms were recorded at $360 \mathrm{~nm}$ and $270 \mathrm{~nm}$.

The mixture of polar constituents was separated using a reverse phase Gemini Phenomenex - C18 RP-18 (Hewlett Packard) column (4.6 mm ×250 mm, $5 \mu \mathrm{m}$ ) and a mobile phase composed of eluent $A(0.1 \%$ aqueous. formic acid) and eluent $\mathrm{B}$ (methanol) at a constant flow rate of $1.0 \mathrm{~mL} \mathrm{~min}{ }^{-1}$ with an oven temperature of $40{ }^{\circ} \mathrm{C}$. The following elution programme was used: 0 min - (20\% B); $10 \min -(30 \%$ B), $20 \min -(50 \%$ B); $30 \min -(70 \%$ B); $40 \mathrm{~min}-(90 \% \mathrm{~B})$; and $45 \mathrm{~min}-(40 \% \mathrm{~B})$, then returning to 
Phytochemical analysis and botanical origin of Apis mellifera bee pollen from the municipality of Canavieiras, Bahia State, Brazil

Negri, G. et al.

the initial conditions (20\% B) to re-equilibrate the column prior to the next run.

The following parameters were used for mass spectrometry: electrospray voltage of the ion source at -38 V, 4,000 V capillary voltage, end plate set at $500 \mathrm{~V}$ and capillary temperature of $300{ }^{\circ} \mathrm{C}$. Helium was used as the collision gas and nitrogen as the nebulizing gas. Dissolution was facilitated using a counter-current nitrogen (dry gas) flow set at 9.0 litres/ minute. The spectra were acquired over a mass-to-charge $(\mathrm{m} / \mathrm{z})$ ranging between 100 and $1200 \mathrm{Da}$ with resolution set at 30,000, based on an average of 10 scans.

The constituents were characterized from their mass spectral (MS) data in the negative and positive ionization modes and using on-line diode array ultraviolet visible spectroscopy, comparing the results with MS data reported in the following computer databases: SciFinder Scholar (https://scifinder.cas.org), Phenol-Explorer (www.phenol-explorer.eu), ChemSpider (http://www.chemspider.com), Knap Sack Core System Knap Sack Core System (http:kanaya.naist.jp) and HMDB (www.hmdb.ca) and also the methods reported by Negri et al. (2011), Yang et al. (2012), Khallouki et al. (2015) and Mihajlovic et al. (2015).

The flavonol-O-glycosides were hydrolysed in an acidic medium, according to the methodology described by Negri et al. (2012), in order to identify the aglycone. This was carried out using the standards quercetin and isorhamnetin from Sigma-Aldrich Chemical Company.

\section{Results and discussion}

The palynological analysis was able to identify Cocos nucifera as the major taxon in the bee pollen sample from Canavieiras (99.0\%), which is explained by the fact that this pollen sample was collected in an area where this plant predominates from January to April, the period in which C. nucifera is in full bloom (LORENZI, 2002). The results differ from those of the bee pollen studied by Dórea et al. (2010) which included polliniferous plant species from the Atlantic Forest biome.

The physicochemical data obtained are shown in Table 1. In the physicochemical analysis, the sample showed moisture $(24.4 \%$, crude sample), ash $(2.54 \%)$, protein (13.15\%), total sugars (33.27\%), and lipids (2.70\%) contents, total acidity of (32.0 meq / $\mathrm{kg})$ and $\mathrm{pH}$ of (4) (Table 1). The protein content was over $8 \%$, which is in accordance with the Brazilian technical regulation (BRASIL, 2001). According to Komosinska-Vassev et al. (2015), pollen contains an average of $22.7 \%$ protein, including $10.4 \%$ of essential amino acids. In the sample from Canavieiras, the amount of protein was lower, which is unusual for bee pollen samples, since this product is a protein source for the hive. According to Liolios et al. (2015) pollens from
Table 1. Physicochemical analyses of a dried Apis mellifera bee pollen sample from the municipality of Canavieiras, Bahia State, Brazil.

\begin{tabular}{ccc} 
Analyses & Contents & Acceptable level \\
\hline Moisture & $24.4 \%{ }^{*}$ & Maximum $30 \%$ \\
Ash & $2.54 \%$ & Maximum $4 \%(\mathrm{~m} / \mathrm{m})$ dry basis \\
Protein & $13.15 \%$ & Minimum $8 \%(\mathrm{~m} / \mathrm{m})$ dry basis \\
Total sugar & $33.27 \%$ & 14.5 to $55(\%)$ dry basis \\
Total acidity & $32.0 \mathrm{meg} / \mathrm{kg}$ & Maximum 300 meg $/ \mathrm{kg}$ \\
pH & 4 & 4 to 6 \\
Lipid & $2.70 \%$ & Minimum $1.8 \%(\mathrm{~m} / \mathrm{m})$ dry basis \\
\hline
\end{tabular}

*non dried sample.

plants blooming in the spring have higher protein contents than those from the summer and autumn.

In the present sample, the protein content and total acidity were lower than the values reported by Bárbara et al. (2015), in which bee pollen samples, also from Bahia-Brazil, but obtained from another two regions: João Dourado and Uibaí, were analysed. This result is not surprising because these authors analysed bee pollen samples from other taxa and another bee species, Melipona mandacaia (Mandacaia stingless bee), not Apis mellifera.

Pollen generally contains $30.8 \%$ of digestible carbohydrates and approximately $25.7 \%$ of reducing sugars, mainly fructose and glucose (KOMOSINSKA-VASSEV et al., 2015). According to Carpes et al. (2009), the total sugar content in the bee pollen is associated with the amount of honey or nectar used by the bees to aggregate the pollen into pellets, allowing for transport to the hives.

The raw bee pollen is a hygroscopic product easily affected by environmental conditions (MARTINS et al., 2011). In the present sample, the moisture content (24.4\%) was lower than the maximum limits established by the Brazilian technical regulation (BRASIL, 2001), which is $30 \%$ for fresh bee pollen.

The non-polar extract was analysed using Infrared (IR) spectroscopy and GC-EI-MS analyses. Infrared spectroscopy has been used in the analysis of natural products, since their biological properties are attributed to certain classes of compounds (ZIMMERMANN; KOHLER, 2014; HUCK, 2015; CAREDDA et al., 2016). Molecules containing the functional groups $\mathrm{C}-\mathrm{H}, \mathrm{O}-\mathrm{H}, \mathrm{N}-\mathrm{H}, \mathrm{C}=\mathrm{O}$, $\mathrm{C}-\mathrm{N}$ and $\mathrm{C}-\mathrm{O}$ are stimulated to stretch-, deform- and carry out scissor vibrations in the 4,000 to $400 \mathrm{~cm}^{-1}$ spectral regions (MULARCZYK-OLIWA et al., 2012; ZIMMERMANN; KOHLER, 2014; CAREDDA et al., 2016).

The IR spectrum exhibited bands at 3369, 2924, 2852, 1742, 1464, 1377, 1241, 1171 and $1090 \mathrm{~cm}^{-1}$, bands associated with different molecular groups. The broad band at $3369 \mathrm{~cm}^{-1}$ was attributed to the presence of hydroxyl groups. The symmetrical and asymmetrical $\mathrm{C}-\mathrm{H}$ stretching bands were at $2852 \mathrm{~cm}^{-1}$ and $2924 \mathrm{~cm}^{-1}$, respectively; 
the $\mathrm{C}-\mathrm{H}$ bending bands at $1464 \mathrm{~cm}^{-1}$ and $1377 \mathrm{~cm}^{-1}$; the $\mathrm{C}=\mathrm{O}$ stretching band of the carboxyl group was at $1742 \mathrm{~cm}^{-1}$ and the $\mathrm{C}-\mathrm{O}$ stretching band of the carboxyl group at $1241 \mathrm{~cm}^{-1}$, indicated the presence of fatty acids, hydrocarbons, phytosterols and esters containing long carbon chains. The strong vibration of the $\mathrm{C}-\mathrm{O}$ single bond of the phytosterols was found in the fingerprint region $\left(1171 \mathrm{~cm}^{-1}\right.$ to $\left.1090 \mathrm{~cm}^{-1}\right)$. Thus the bands exhibited an IR spectrum that indicated the presence of fatty acids, hydrocarbons and phytosterols, which was corroborated by the results obtained in the GC-EI-MS analysis.

The constituents detected in non-polar extract are shown in Table 2. Constituents 1-25 were detected in the non-polar extract by means of GC-EI-MS. Fatty acids $(1,3-5,8,11)$, hydrocarbons $(6,9,13-16,19)$, phytosterols $(17,18,20-23)$, as well as the diterpene kaur-16-ene (2) and esters containing long carbon chains, such as the hexanoic acid undecyl ester (7), the hexanoic acid nonadecyl ester (10), the hexadecanoic acid octadecyl ester (24) and the octadecanoic acid octadecyl ester (25) (Table 2), were identified from their respective MS data, which were compared with MS data previously reported in the literature (KAFFARNIK et al., 2014; OLVERA-GARCIA et al., 2015).

The main constituents detected in the non-polar extract were fatty acids such as palmitic acid (1) (13.33\%), oleic acid (4) (10.56\%), behenic acid (8) (7.18\%), hexanoic acid nonadecyl ester (10) (9.73\%), and also hydrocarbons such as 9-heptacosene (15) (4.95\%), 9-hentriacontene (16) $(6.07 \%)$ and 13 -tritriacontene (19) (8.21\%). Phytosterols were detected in smaller amounts, and the most abundant were sitosterol (20) (3.24\%) and fucosterol (21) (2.89\%) (Table 2). Thus a predominance of saturated fatty acids was observed in the bee pollen sample under analysis. The most abundant $n$-alkanes detected in bee pollen samples were the odd-numbered carbon atom series C27, C29, C23, C17, and C21, while the sterol composition consisted mainly of $\beta$-sitosterol and stigmastan-3,5-diene (BASHIR et al., 2013).

According to Komosinska-Vassev et al. (2015), fatty acids were the main lipid constituents of bee pollen and constituted approximately $5.1 \%$. Linoleic, y-linoleic and arachidic acids constitute $0.4 \%$, whereas phytosterols, especially sitosterol, constituted 1.1\% (KOMOSINSKA-VASSEV et al., 2015). Palmitic, linoleic and $\alpha$-linolenic acids were the main fatty acids found in bee pollen samples from M. mandacaia collected in another two regions of Bahia State in Brazil (BÁRBARA et al., 2015). The dichloromethane extract from Greek bee pollen contained fatty acids and fatty acid esters (GRAIKOU et al., 2011).

On average, unsaturated fatty acids constitute about $70 \%$ of the total lipids (CAMPOS et al., 2008). There are generally greater amounts of unsaturated fatty acids in bee pollen than saturated fatty acids, with levels between $43 \%$ and $70 \%$ of total fatty acids (BASHIR et al., 2013;
BÁRBARA et al., 2015). According to Estevinho et al., (2012), the bees choose pollens with larger amounts of unsaturated fatty acids because these are more adequate for their metabolism. The hypoglycemic activity of the pollen was mainly attributed to the presence of unsaturated fatty acids, phospholipids and phytosterols (KOMOSINSKA-VASSEV et al., 2015).

The polar extract of the bee pollen sample evaluated here was analysed by means of HPLC-DAD-ESI-MS/MS. The constituents, shown in Table 3, were identified based on their UV spectra and MS data, which were compared with previously reported MS data for bee pollen constituents. Many bee pollen samples exhibited high contents of hydroxycinnamic acid amide derivatives or triacylated spermidines, and flavonol glycosides.

Thus the MS data for the flavonol glycosides and hydroxycinnamic acid amides detected in this polar extract of the bee pollen were compared with the MS data reported by Sobolev et al. (2008), Fellenberg et al. (2009), Freire et al. (2012), Goupy et al. (2013), Khallouki et al. (2015) and Mlhajlovic et al. (2015).

Compounds 28-31, 33 and 34 were characterized as flavonol glycosides according to the typical maximum UV absorption at $255-355 \mathrm{~nm}$ (Table 3). Flavonoids in the form of aglycones are rarely found in pollens and in plants, since they are generally linked to sugars. Flavonol-O-glycosides with a free hydroxyl group in the C3-O position exhibit maximum UV band I at $374 \mathrm{~nm}$, whereas flavonols with a blocked hydroxyl at the C3-O position exhibit maximum UV band I between $340 \mathrm{~nm}$ to $360 \mathrm{~nm}$ (CAMPOS; MARKHAM, 2007; RODRIGUEZ-PÉREZ et al., 2013; SIMIRGIOTIS et al., 2013). Band I at $355 \mathrm{~nm}$ indicated that the sugar substitution occurred on the hydroxyl group at the C3-O position of flavonols 28-31, 33 and 34 (CAMPOS; MARKHAM, 2007). Quercetin and isorhamnetin were identified as aglycones in the flavonol-3-O-glycosides 28-31, 33 and 34 after hydrolysis, which was confirmed by matching the retention time, the UV data, the MS spectral data and the co-injection with standards (data not shown).

Compound 28 exhibited a [M - H]- ion at $\mathrm{m} / \mathrm{z} 609$ in the ESI-MS spectrum and the ion $\mathrm{m} / \mathrm{z} 301$ in the MS/MS spectrum, attributed to deprotonated quercetin as the aglycone. Compound 28 was identified as quercetin-3-0rhamnosylglucoside. Compound 29 exhibited a [M - H]- ion at $\mathrm{m} / \mathrm{z} 639$ and the ion $\mathrm{m} / \mathrm{z} 477$ in the MS/MS spectrum, which was formed by the loss of the glucose moiety (162 Da). The O-glycosidic bond is more labile at position 7 , and consequently its breakdown is favoured (GOUPY et al., 2013). The base peak at $\mathrm{m} / \mathrm{z} 315$ corresponds to deprotonated isorhamnetin (3'-O-methyl quercetin), formed after the loss of the second glucose unit. These MS data agree with those reported by Goupy et al. (2013), and compound $\mathbf{2 9}$ was assigned as isorhamnetin-di-3,7-O-glucoside. 
Phytochemical analysis and botanical origin of Apis mellifera bee pollen from the municipality of Canavieiras, Bahia State, Brazil

Negri, G. et al.

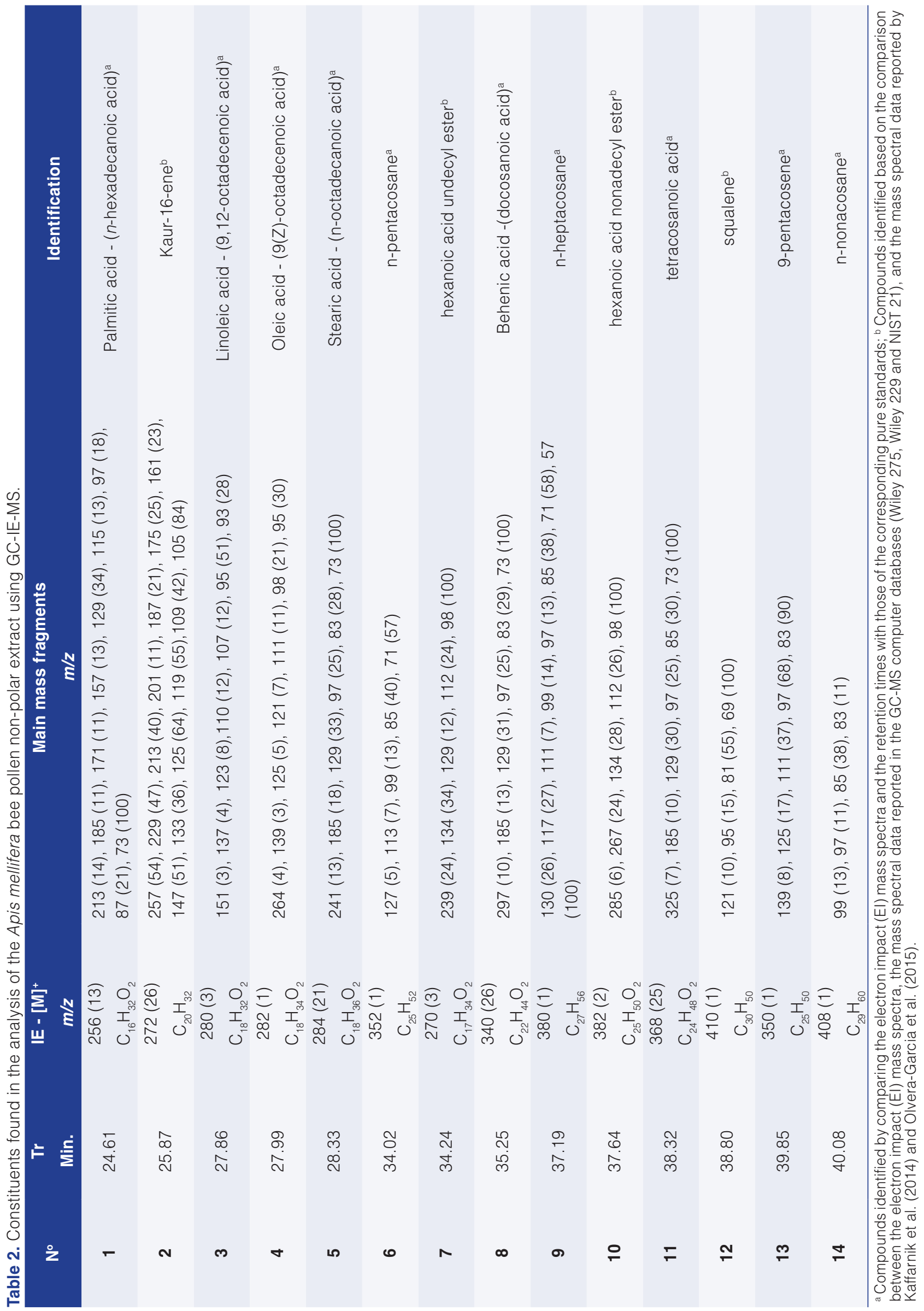


Phytochemical analysis and botanical origin of Apis mellifera bee pollen from the municipality of Canavieiras, Bahia State, Brazil

Negri, G. et al.

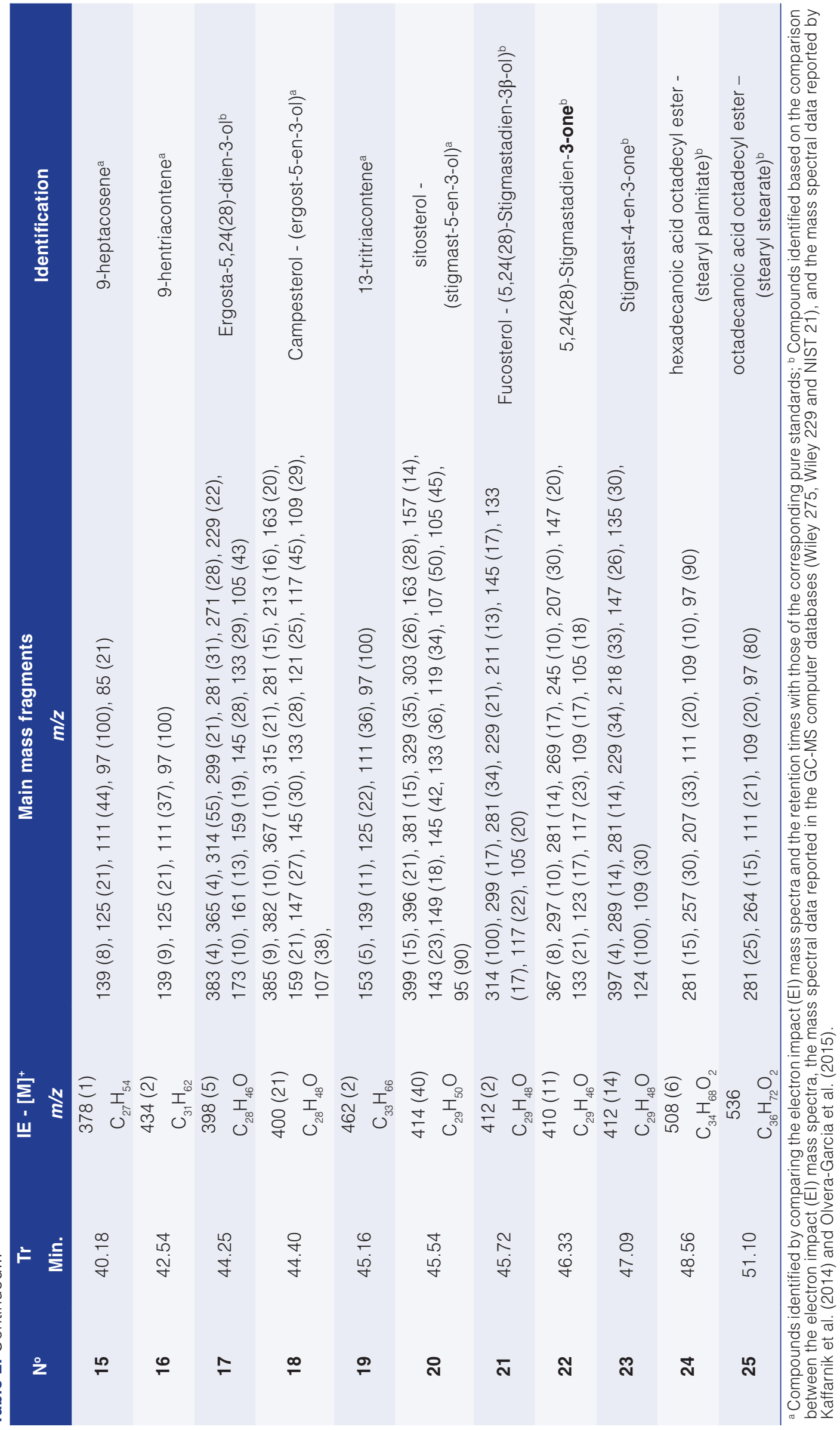


Phytochemical analysis and botanical origin of Apis mellifera bee pollen from the municipality of Canavieiras, Bahia State, Brazil

Negri, G. et al.

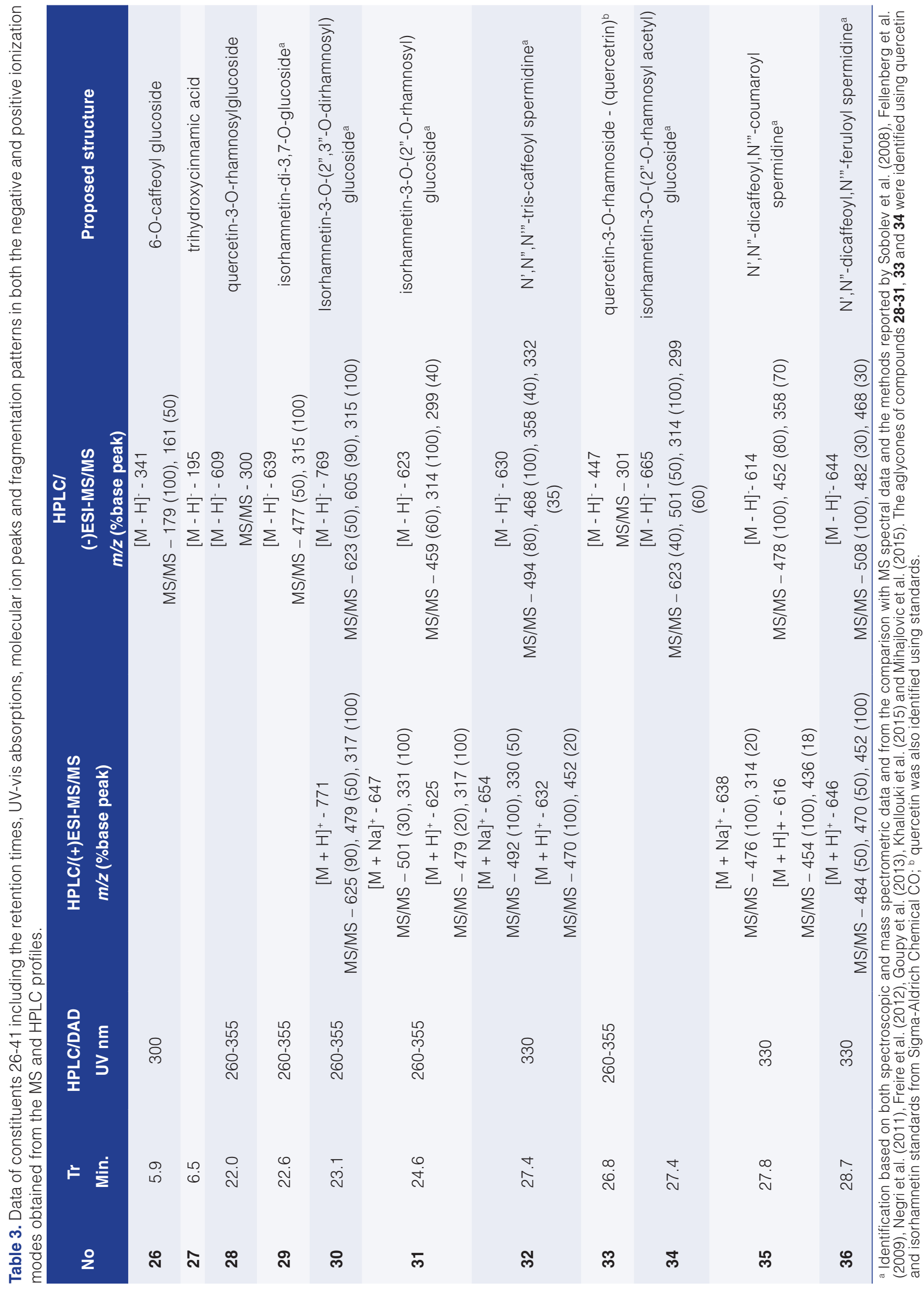


Phytochemical analysis and botanical origin of Apis mellifera bee pollen from the municipality of Canavieiras, Bahia State, Brazil

Negri, G. et al.

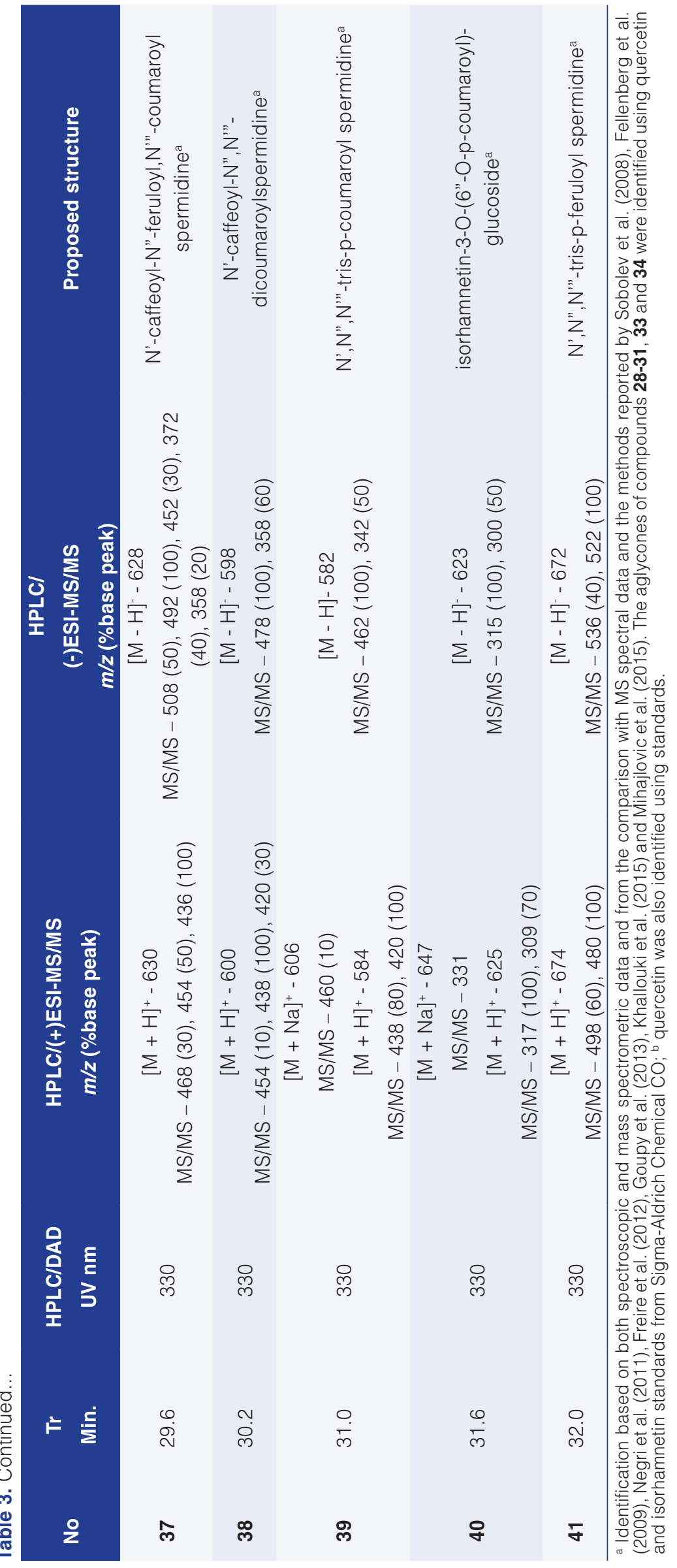


Isorhamnetin-3-O-(2",3"-O-dirhamnosyl) glucoside and isorhamnetin-3-O-(2"-O-rhamnosyl) glucoside have been previously reported in bee pollen (NEGRI et al., 2011). Compound 30 exhibited a [M - H] ion at $\mathrm{m} / \mathrm{z} 769$, which, after the MS/MS experiments produced an ion fragment at $\mathrm{m} / \mathrm{z} 623$, indicating the loss of the rhamnose moiety (146 Da). It also produced an ion fragment at $m / z 605[\mathrm{M}-\mathrm{H}-164]$; which was attributed to the loss of rhamnose and water moieties, characteristic of $O$-glycosylation at the hydroxyl group in position 2" of the glucose in C-glycosyl flavonols-Oglycosylated (FERRERES et al., 2010; DINELLI et al., 2011). The base peak at $m / z 315$ corresponded to deprotonated isorhamnetin, which was formed after the loss of the glucosyl unit. Moreover, compound 30 exhibited a $[\mathrm{M}+\mathrm{H}]^{+}$ion at $\mathrm{m} / \mathrm{z} 771$, which produced ion fragments at $\mathrm{m} / \mathrm{z} 625$ and at $\mathrm{m} / \mathrm{z} 479$, resulting from the loss of two rhamnose moieties, and it also produced a base peak at $\mathrm{m} / \mathrm{z} 317$ (protonated isorhamnetin). These MS spectral data agree with those reported by Negri et al. (2011), and compound 30 was assigned as isorhamnetin-3-O-(2",3"-O-dirhamnosyl) glucoside.

Compound 31 was the main constituent detected in the polar extract and showed molecular ion peaks at $\mathrm{m} / \mathrm{z} 623$ and $\mathrm{m} / \mathrm{z} 625$ and a sodium adduct at $\mathrm{m} / \mathrm{z} 647$. In the negative ionization mode, the MS/MS experiments produced an ion fragment at $\mathrm{m} / \mathrm{z} 459$, resulting from the loss of rhamnose and water moieties. The ion fragments at $\mathrm{m} / \mathrm{z} 314$ (100) and 299 (40) indicated isorhamnetin as the aglycone. According to Rodríguez-Pérez et al. (2013) and Simirgiotis et al. (2013), the ion fragment at $\mathrm{m} / \mathrm{z} 314$ was produced by the homolytic cleavage of the $\mathrm{O}$-glycosidic bond at the C3-O position of flavonol, and resulted in the formation of a aglycone anion radical of isorhamnetin. On the other hand, the MS/MS experiments in the positive ionization mode produced ion fragments at $\mathrm{m} / \mathrm{z} 479$ and a base peak at $\mathrm{m} / \mathrm{z} 317$ (protonated isorhamnetin), corresponding to the loss of rhamnose and glucose, respectively (KHALLOUKI et al., 2015). Protonated molecules are able to form adducts, clusters and/or molecular complexes with the mobile phase, such as the sodium adduct $[\mathrm{M}+\mathrm{Na}]^{+}$at $22 \mathrm{Da}$ instead of the proposed protonated molecule in the positive ionization mode. The sodium adduct exhibited $[\mathrm{M}+\mathrm{H}+\mathrm{Na}]^{+}$at $\mathrm{m} / \mathrm{z}$ 647, which, after the MS/MS experiments, yielded a base peak at $m / z 331$, representing the protonated rhamnosyl glucoside moiety plus sodium. These MS spectral data agree with those reported by Negri et al. (2011), and compound 31 was assigned as isorhamnetin-3-O-(2"-Orhamnosyl) glucoside.

Compound 40 also exhibited molecular ion peaks at $m / z 623$ and $m / z 625$ and a sodium adduct at $m / z 647$, as did compound 31; however it exhibited maximum UV absorption at $330 \mathrm{~nm}$. Flavonoid glycosides esterified with aromatic acids exhibit longer Rt on the RP-HPLC column and their UV spectra exhibit intense band I (approximately $330 \mathrm{~nm}$ ) and a small band II at $270 \mathrm{~nm}$, resulting from the UV absorption overlap of the flavonoid and the cinnamoyl groups. The predominant bonding site of the acyl groups was usually the 6"-position of hexose; however, other positions should not be excluded (ABAD-GARCÍA et al., 2009). The MS/MS experiments in the negative ionization mode produced a base peak at $\mathrm{m} / \mathrm{z} 315$ (deprotonated isorhamnetin), resulting from the loss of $308 \mathrm{Da}$ ( $p$-coumaroylglucoside moiety). The MS/MS experiments in the positive ionization mode exhibited a base peak at $\mathrm{m} / \mathrm{z} 317$ (protonated isorhamnetin) and an ion fragment at $\mathrm{m} / \mathrm{z} 309$, attributed to the protonated $p$-coumaroyl-glucoside moiety. The sodium adduct provided a molecular ion peak at $m / z 647$, which fragmented to yield a base peak at $m / z 331$, representing the protonated p-coumaroyl-glucoside moiety plus sodium. Compound 40 was tentatively assigned as isorhamnetin3-O-(6"-O-p-coumaroyl)-glucoside, from its UV and mass spectral fragmentation patterns.

Compound 34 exhibited a $[\mathrm{M}-\mathrm{H}]^{-}$ion at $\mathrm{m} / \mathrm{z} 665$, which after the MS/MS experiments exhibited ion fragments at $m / z 623$ and $m / z 501$, along with ion fragments attributed to isorhamnetin at $m / z 314$ and $m / z$ 299. Compound 34 had another $42 \mathrm{Da}$ indicating the presence of an acetyl group, which was also observed from the ion fragment at $\mathrm{m} / \mathrm{z}$ 623. Acylated flavonol glycosides eluted after their corresponding flavonol glycosides under reversed phase conditions (RODRÍGUEZ-PÉREZ et al., 2013). Based on its mass spectral data, compound 34 was tentatively assigned as isorhamnetin-3-O-(2"-O-rhamnosyl acetyl) glucoside. Compound 33 exhibited a [M - H] ion at $\mathrm{m} / \mathrm{z} 447$, which after the MS/MS experiments produced a base peak at $\mathrm{m} / \mathrm{z} 301$, indicating quercetin as the aglycone. Compound 33 was identified as quercetin-3-O-rhamnoside, also known as quercetrin, based on an authentic standard.

Compounds 32, 35-39 and 41 were characterized as hydroxycinnamic acid amide (HCA) derivatives, according to the typical maximum UV absorption at $330 \mathrm{~nm}$ (Table 3). Hydroxycinnamic acid amides (HCA) may undergo isomerization of their double bonds, and yield $\mathrm{E} / \mathrm{Z}$ isomers. In addition, they may undergo positional isomerism and present complex fragmentation behaviours (YANG et al., 2012). MS/MS experiments with protonated HCA produce abundant ion fragments attributed to neutral acyl losses; for example, $176 \mathrm{Da}$ for feruloyl, $162 \mathrm{Da}$ for caffeoyl, and $146 \mathrm{Da}$ for the coumaroyl moieties, followed by neutral water loss (NEGRI et al., 2011). MS/MS experiments with deprotonated HCA produce abundant ion fragments attributed to the loss of $120 \mathrm{Da}$, corresponding to the coumaric acid moiety; to the loss of 136 Da corresponding to the caffeic acid moiety; and to the loss of $150 \mathrm{Da}$ corresponding to the ferulic acid moiety (YANG et al., 2012; MIHAJLOVIC et al., 2015). 
Compounds 32 and 35 exhibited a $[\mathrm{M}+\mathrm{H}]^{+}$ion at $\mathrm{m} / \mathrm{z} 632$ and $\mathrm{m} / \mathrm{z} 616$, respectively. Their MS/MS fragmentation patterns were similar in both the positive and negative ionization modes and exhibited base peaks derived from neutral caffeoyl losses at $\mathrm{m} / \mathrm{z} 470$ and $\mathrm{m} / \mathrm{z} 454$ and ion fragments derived from water loss at $\mathrm{m} / \mathrm{z} 452$ and $\mathrm{m} / \mathrm{z} 436$, respectively, in the positive ionization mode. The sodium adduct at $m / z 654$ (for 32 ) and at $m / z 638$ (for 35 ) produced ion fragments derived from two neutral caffeoyl losses at m/z 492 and m/z 330 and at $\mathrm{m} / \mathrm{z} 476$ and $\mathrm{m} / \mathrm{z} 314$, respectively. Compounds 32 and 35 exhibited [M - H] ions at $\mathrm{m} / \mathrm{z} 630$ and $\mathrm{m} / \mathrm{z} 614$, respectively. Their MS/MS fragmentation produced an ion fragment derived from neutral caffeoyl losses at $\mathrm{m} / \mathrm{z} 468$ and $\mathrm{m} / \mathrm{z}$ 452 , corresponding to the loss of two caffeic acid moieties (136 Da) at $\mathrm{m} / \mathrm{z} 494$ and $\mathrm{m} / \mathrm{z} 358$ and at $\mathrm{m} / \mathrm{z} 478$ and $\mathrm{m} / \mathrm{z}$ 358 , respectively. Based on the mass spectral data and the method reported by Negri et al. (2011), Yang et al. (2012), and Mihajlovic et al. (2015), compound 32 was assigned as $\mathrm{N}^{\prime}, \mathrm{N}^{\prime}, \mathrm{N}^{\prime \prime}$--tris-caffeoyl spermidine and compound 35 as N',N"-dicaffeoyl,N"'-coumaroyl spermidine.

Compounds 36 and 37 exhibited molecular ion peaks at $m / z 646$ and $m / z 630$, respectively. MS/MS experiments in the positive ionization mode, produced ion fragments derived from neutral caffeoyl losses at $\mathrm{m} / \mathrm{z} 484$ and $\mathrm{m} / \mathrm{z}$ 468 , derived from neutral feruloyl losses at $\mathrm{m} / \mathrm{z} 470$ and $\mathrm{m} / \mathrm{z} 454$ and base peaks derived from water loss at $\mathrm{m} / \mathrm{z}$ 452 and $\mathrm{m} / \mathrm{z} 436$, respectively. In the negative ionization mode, the fragmentation patterns for compounds 36 and 37 were different. Compound 36 exhibited a $[\mathrm{M}-\mathrm{H}]$ - ion at $m / z 644$, which produced an ion fragment derived from neutral caffeoyl loss at $\mathrm{m} / \mathrm{z} 482$, at $\mathrm{m} / \mathrm{z} 468$, derived from neutral feruloyl losses at $\mathrm{m} / \mathrm{z} 468$ and a base peak at $\mathrm{m} / \mathrm{z} 508$, resulting from the loss of a caffeic acid moiety. On the other hand, compound 37 exhibited a $[\mathrm{M}-\mathrm{H}]$ - ion at $\mathrm{m} / \mathrm{z} 628$, which produced an iuon fragment derived from neutral feruloyl loss at $\mathrm{m} / \mathrm{z} 452$, corresponding to the loss of a coumaric acid moiety at $\mathrm{m} / \mathrm{z} 508$, and a base peak at $m / z 492$, corresponding to the loss of a caffeic acid moiety. Based on the MS data and the method reported by Negri et al. (2011), Yang et al. (2012), and Mihajlovic et al. (2015), compound 36 was assigned as N',N"-dicaffeoyl,N'"-feruloyl spermidine and compound 37 as N'-caffeoyl-N"-feruloyl, N'"-coumaroyl spermidine.

Compound 38 showed a $[\mathrm{M}+\mathrm{H}]^{+}$ion at $\mathrm{m} / \mathrm{z} 600$, which produced an ion fragment at $\mathrm{m} / \mathrm{z} 454$ derived from neutral coumaroyl losses and a base peak at $\mathrm{m} / \mathrm{z} 438$, derived from neutral caffeoyl losses, as well as an ion fragment at $\mathrm{m} / \mathrm{z}$ 420. Besides this, compound 38 exhibited a $[\mathrm{M}-\mathrm{H}]$ - ion at $\mathrm{m} / \mathrm{z} 598$, which produced a base peak at $\mathrm{m} / \mathrm{z} 478$ and an ion fragment at $m / z 358$, both corresponding to the loss of a coumaric acid moiety. These MS data agree with those reported by Mihajlovic et al. (2015) and compound 38 was assigned as N'-caffeoyl-N",N'"- dicoumaroyl spermidine.
Compound 39 exhibited a $[\mathrm{M}+\mathrm{H}]^{+}$ion at $\mathrm{m} / \mathrm{z} 584$, which produced an ion fragment derived from neutral coumaroyl losses at $m / z 438$, and a base peak at $m / z 420$. The MS/MS experiments on the sodium adduct at $\mathrm{m} / \mathrm{z} 606$ produced a base peak derived from neutral coumaroyl losses at $\mathrm{m} / \mathrm{z} 460$. Besides this, compound 39 showed a $[\mathrm{M}-\mathrm{H}]^{-}$ion peak at $\mathrm{m} / \mathrm{z} 582$, which produced a base peak at $\mathrm{m} / \mathrm{z} 462$ and an ion fragment at $\mathrm{m} / \mathrm{z} 342$, both corresponding to the loss of a coumaric acid moiety. Since the ion fragments of compound 39 matched those reported by Negri et al. (2011) and Mihajlovic et al. (2015), it was assigned as N',N",N'"-tris-p-coumaroyl spermidine.

Compound 41 exhibited a $[\mathrm{M}+\mathrm{H}]^{+}$ion at $\mathrm{m} / \mathrm{z} 674$, which produced an ion fragment derived from neutral feruloyl losses at $m / z 498$, and a base peak at $m / z 480$. Besides this, compound 41 showed a $[\mathrm{M}-\mathrm{H}]$ ] ion at $\mathrm{m} / \mathrm{z}$ 672 , that produced an ion fragment corresponding to the loss of a ferulic acid moiety at m/z 536 and a base peak at $m / z$ 522. These MS spectral data agree with those reported by Negri et al. (2011), and compound 41 was assigned as N',N",N'"-tris-p-feruloyl spermidine. Tables 1 - Physicochemical analyses of a dried Apis mellifera bee pollen sample; 2 - Constituents detected in the analysis of the non-polar extract using GC-IE-MS and 3 - Constituents detected in the analysis of the polar extracts in both the negative and positive ionization modes obtained from the MS and HPLC profiles, together with the mass spectra of the constituents detected in this bee pollen sample (Supplementary Material, Figures 1S-48S) were provided as supporting information. The structures of these compounds will require confirmation in future NMR experiments when sufficient pure material is available.

Of the compounds present in the pollen, the phenolic acids and polyphenolic compounds such as flavonoids are a very important group of bioactive structures, useful in a vast range of applications. One point four percent (1.4\%) are flavonoids occurring mainly as glycosides of kaempferol, quercetin, and isorhamnetin, whereas $0.2 \%$ of the phenolic acids correspond mainly to chlorogenic acid (KOMOSINSKA-VASSEV et al., 2015) and caffeic acid derivatives (CAMPOS et al., 1997, 2003). In Typha angustifolia L. pollen, the main active compounds found were flavonoids (TAO et al., 2011). High contents of flavonol glycosides and aglycones were found in the bee pollen produced in Bahia State, Brazil (FREIRE et al., 2012). Quercetin and kaempferol glycosides were detected in many taxa, for example: Eucalyptus globulus, Salix atrocinera, Helianthus annus, Raphanus raphanistrum, Erica australis and Cistus angustifolia. The taxa originated from different countries ranging from Portugal to New Zealand (CAMPOS et al., 1997). They were also detected in the rape bee pollen collected from the Qinghai-Tibetan Plateau (LV et al., 2015). Benzoic acid derivatives and hydroxycinnamic acids have also been identified in pollen 
Phytochemical analysis and botanical origin of Apis mellifera bee pollen from the municipality of Canavieiras, Bahia State, Brazil

Negri, G. et al.

(GRAIKOU et al., 2011). Castanea pollen exhibited high polyphenol, flavonoid and anthocyanin contents, while a high content of flavonols was detected in Cistus pollen (GABRIELE et al., 2015).

Spermidine derivatives are compounds not always identified in pollen samples and give extra information that helps to compliment research into structures involved in the bioactivities explored in this raw material. In Ambrosia artemisiifolia L. pollen, flavonoids were detected as monoglycosides and malonyl-mono- and diglycosides of isorhamnetin, quercetin and kaempferol, whereas the spermidine derivatives were identified as the dominant polyamides (MIHAJLOVIC et al., 2015). N',N",N'"-Trisp-feruloyl spermidine and N',N",N'"-tris-p-coumaroyl spermidine were found in seven bee pollen samples from different palynological sources harvested in the municipality of Pindamonhangaba (South-eastern Brazil) (NEGRI et al., 2011).

Fatty acids and esters, phytosterols, flavonol glycosides and triacylated spermidines exhibit important biological activities such as antioxidant activity, free radical scavenging capacity, coronary heart disease prevention, as well as hepatoprotective, anti-inflammatory, anticancer and antimicrobial activities, amongst others. Flavonoids acting as antioxidant compounds can prevent oxidative stress, which leads to disorders that affect the central nervous system. In addition, flavonoids can also modulate both enzyme and receptor activities (GROSSO et al., 2013). Quercetin and isorhamnetin derivatives exhibit free radical scavenging capacity, coronary heart disease prevention, and hepatoprotective, anti-inflammatory, anticancer (KUMAR; PANDEY, 2013), antioxidant and antiviral (FRIEDMAN, 2014) activities.

Spermidine is an endogenous polyamine with a polycationic structure found in the central nervous system of mammals and it regulates biological processes such as the $\mathrm{Ca}^{2+}$ influx by the glutamatergic N-methyl-D-aspartate receptor (CARVALHO et al., 2012). Several important control functions in cells, ranging from the basic DNA synthesis to the regulation of cell proliferation and differentiation, were attributed to polyamines such as spermidine and spermine and their precursor putrescine (MINOIS et al., 2011; CHOI; PARK, 2012). Spermidine derivatives are also able to improve locomotor performance in the aging (MINOIS, 2014; MINOIS et al., 2014). In addition they exhibited antimicrobial activity against viruses, bacteria and fungi, and have been related to protection against pathogens (MIHAJLOVIC et al., 2015).

\section{Conclusion}

Bee pollen has been used for many years as a beneficial dietary supplement. Fatty acids and esters were the main constituents found in the dichloromethane extract of the bee pollen sample collected in the municipality of
Canavieiras, in an area with the predominance of $C$. nucifera. They were followed by smaller amounts of phytosterols and hydrocarbons, whereas large amounts of flavonol glycosides and triacylated spermidines were found in the polar extracts. Flavonoids and di- and triacylated spermidines were reported as the main constituents found in many other pollen and bee pollen samples.

\section{Acknowledgements}

The authors are grateful to the Sao Paulo Research Foundation (FAPESP) for the financial support; and would also like to thank "Strategic Project RG-Centre-177-3717 from the Science and Technology Foundation", UID/ QUI/00313/2013 and POCI-01-0145-FEDER-007630 (Portugal).

\section{References}

ABAD-GARCÍA, B.; BERRUETA, L. A.; GARMÓN-LOBATO, S.; GALLO, B.; VICENTE, F. A general analytical strategy for the characterization of phenolic compounds in fruit juices by highperformance liquid chromatography with diode array detection coupled to electrospray ionization and triple quadrupole mass spectrometry. Journal of Chromatography A, v. 1216, n. 28, p. 5398-5415, 2009. http://dx.doi.org/10.1016/j.chroma.2009.05.039.

ARCHINI, L. C.; ACÁCIO DOS REIS, V. D.; MORETI, A. C. C. C. Composição físico-química de amostras de pólen coletado por abelhas Africanizadas Apis mellifera (Hymenoptera: Apidae) em Piracicaba, Estado de São Paulo. Ciência Rural, v. 36, n. 9, p. 949-953, 2006.

BÁRBARA, M.; MACHADO, C.; SODRÉ, G.; DIAS, L.; ESTEVINHO, L.; CARVALHO, C. A. Microbiological assessment, nutritional characterization and phenolic compounds of bee pollen from Mellipona mandacaia Smith, 1983. Molecules, v. 20, n. 12, p. 12525-12544, 2015. http://dx.doi.org/10.3390/molecules200712525.

BASHIR, M. E. H.; LUI, J. H.; PALNIVELU, R.; NACLERIO, R. M.; PREUSS, D. Pollen lipidomics: lipid profiling exposes a notable diversity in 22 allergenic pollen and potential biomarkers of the allergic immune response. PLoS One, v. 8, n. 2, p. e57566, 2013. http://dx.doi.org/10.1371/journal.pone.0057566. PMid:23469025.

BRASIL. Ministério da Agricultura, Pecuária e Abastecimento. Instrução Normativa n 3, de 19 de janeiro de 2001. Regulamentos técnicos de identidade e qualidade, de apitoxina, de cera de abelha, de geléia real, de geléia real liofilizada, de pólen apícola, de própolis, de extrato de própolis. Diário Oficial [da] República Federativa do Brasil, Brasília, DF. 2001.

CAMPOS, M. G. R.; BOGDANOV, S.; DE ALMEIDA-MURADIAN, L. B.; SZCZESNA, T.; MANCEBO, Y.; FRIGERIO, C.; FERREIRA, F. Pollen composition and standardization of analytical methods. Journal Apicultural Research Bee World, v. 47, n. 2, p. 154-161, 2008. http://dx.doi.org/10.1080/00218839.2008.11101443. 
Phytochemical analysis and botanical origin of Apis mellifera bee pollen from the municipality of Canavieiras, Bahia State, Brazil

Negri, G. et al.

CAMPOS, M. G. R.; MARKHAM, K. R. (Ed.). Structure information from hplc and on-line measured absorption spectra: flavone, flavonols and phenolic acids. Portugal: Coimbra University Press, 2007. 118 p. http://dx.doi.org/10.14195/978-989-26-0480-0.

CAMPOS, M. G.; WEBBY, R. F.; MARKHAM, K. R.; MITCHELL, K. A.; DA CUNHA, A. P. Age-induced diminution of free radical scavenging capacity in bee pollens and the contribution of constituent flavonoids. Journal of Agricultural and Food Chemistry, v. 51, n. 3, p. 742-745, 2003. http://dx.doi.org/10.1021/ jf0206466. PMid:12537451.

CAMPOS, M.; MARKHAM, K. R.; MITCHELL, K. A.; DA CUNHA, A. P. An approach to the characterization of bee pollens via their flavonoid/phenolic profiles. Phytochemical Analysis, v. 8, n. 4, p. 181-185, 1997. http://dx.doi.org/10.1002/(SICI)10991565(199707)8:4<181::AID-PCA359>3.0.CO;2-A

CAREDDA, M.; ADDIS, M.; IBBA, I.; LEARDI, R.; SCINTU, M. F.; PIREDDA, G.; SANNA, G. Prediction of fatty acid content in sheep milk by Mid-Infrared spectrometry with a selection of wave lengths by Genetic Algorithms. LWT-Food Science Technology, v. 65, $n$. 4, p. 503-510, 2016. http://dx.doi.org/10.1016/j.Iwt.2015.08.048.

CARPES, S. T.; MOURÃO, G. B.; ALENCAR, S. M.; MASSON, M. $L$. Chemical composition and free radical scavenging activity of Apis mellifera bee pollen from Southern Brazil. Brazilian Journal of Food Technology, v. 12, n. 3, p. 220-229, 2009. http://dx.doi. org/10.4260/BJFT2009800900016.

CARVALHO, F. B.; MELLO, C. F.; MARISCO, P. C.; TONELLO, R.; GIRARDI, B. A.; FERREIRA, J.; OLIVEIRA, M. S.; RUBIN, M. A. Spermidine decreases $\mathrm{Na}+, \mathrm{K}+$-ATPase activity through NMDA receptor and protein kinase $\mathrm{G}$ activation I the hippocampus of rats. European Journal of Pharmacology, v. 684, n. 1-3, p. 79-86, 2012. http://dx.doi.org/10.1016/j.ejphar.2012.03.046. PMid:22497998.

CHEN, Y.; YU, H.; WU, H.; PAN, Y.; WANG, K.; JIN, Y.; ZHANG, C. Characterization and quantification by LC-MS/MS of the chemical components of the heating products of the flavonoids extract in pollen typhae for transformation rule exploration. Molecules, v. 20 , n. 10 , p. 18352-18366, 2015. http://dx.doi.org/10.3390/ molecules201018352. PMid:26457703.

CHOI, Y. H.; PARK, H. Anti-inflammatory effects of spermidine in lipopolysaccharide-stimulated BV2 microglial cells. Journal Biomedical Science, v. 19, n. 1, p. 31-36, 2012. http://dx.doi. org/10.1186/1423-0127-19-31. PMid:22433014.

DINELLI, G.; SEGURA-CARRETERO, A.; DI SILVESTRO, R.; MAROTTI, I.; ARRÁEZ-ROMÁN, D.; BENEDETTELLI, S. Profiles of phenolic compounds in modern and old common wheat varieties determined by liquid chromatography coupled with time-of-flight mass spectrometry. Journal of Chromatography A, v. 1218, n. 42, p. 7670-7681, 2011. http://dx.doi.org/10.1016/j. chroma.2011.05.065

DÓREA, M. C.; NOVAIS, J. S.; RIBEIRO DOS SANTOS, F. A. Botanical profile of bee pollen from the Southern Coastal
Region of Bahia, Brazil. Acta Botânica Brasileira, v. 24, n. 3, p. $862-867,2010$

ERDTMAN, G. The Acetolysis method: in a revised description. Svensk Botanisk Tidskrift, v. 54, n. 4, p. 561-564, 1960.

ESTEVINHO, L. M.; RODRIGUES, S.; PEREIRA, A. P.; FEÁS, $X$. Portuguese bee pollen: palynological study, nutritional and microbiological evaluation. International Journal Food Science Technology, v. 47, n. 2, p. 429-435, 2012. http://dx.doi. org/10.1111/j.1365-2621.2011.02859.x.

FEÁS, X.; VÁZQUEZ-TATO, M. P.; ESTEVINHO, L. M.; SEIJAS, J. A.; IGLESIAS, A. Organic bee pollen: botanical origin, nutritional value, bioactive compounds, antioxidant activity and microbiological quality. Molecules, v. 17, n. 7, p. 8359-8377, 2012. http://dx. doi. org/10.3390/molecules17078359. PMid:22785265.

FELLENBERG, C.; BÖTTCHER, C.; VOGT, T. Phenylpropanoidpolyamine conjugate biosynthesis in Arabidopsis thaliana flower buds. Phytochemistry, v. 70, n. 11, p. 1392-1400, 2009. http://dx. doi. org/10.1016/j. phytochem.2009.08.010. PMid:19762055.

FERRERES, F.; PEREIRA, D. M.; VALENTÃO, P.; ANDRADE, P. B. First report of non-coloured flavonoids in Echium plantagineum bee pollen: differentiation of isomers by liquid chromatography / ion trap mass spectrometry. Rapid Communications in Mass Spectrometry, v. 24, n. 6, p. 801-806, 2010. http://dx.doi. org/10.1002/rcm.4454. PMid:20187084

FREIRE, K. R. L.; LINS, A. C. S.; DÓREA, M. C.; SANTOS, F. A. R.; CAMARA, C. A.; SILVA, T. M. S. Palynological origin, phenolic content, and antioxidant properties of honeybee-collected pollen from Bahia, Brazil. Molecules, v. 17, n. 2, p. 1652-1664, 2012. http://dx.doi.org/10.3390/molecules17021652. PMid:22314384.

FRIEDMAN, M. Antibacterial, antiviral and antifungal properties of wines and winery by products in relation to their flavonoid content. Journal Agricultural Food Chemistry, v. 62, n. 26, p. 60256042, 2014. http://dx.doi.org/10.1021/jf501266s. PMid:24945318.

GABRIELE, M.; PARRI, E.; FELICIOLI, A.; SAGONA, S.; POZZO, L.; BIONDI, C.; DOMENICI, V.; PUCCI, L. Phytochemical composition and antioxidant activity of Tuscan bee pollen of different botanic origins. Italian Journal of Food Science, $v$. 27, n. 2, p. 248-259, 2015.

GOUPY, P.; VIAN, M. A.; CHEMAT, F.; CARIS-VEYRAT, C. Identification and quantification of flavonols, anthocyanins and lutein diesters in tepals of Crocus sativus by ultra performance liquid chromatography coupled to diode array and ion trap mass spectrometry detections. Industrial Crops Products, v. 44, n. 1 , p. 496-510, 2013. http://dx.doi.org/10.1016/j.indcrop.2012.10.004.

GRAIKOU, K.; KAPETA, S.; ALIGIANNIS, N.; SOTIROUDIS, G.; CHONDROGIANNI, N.; GONOS, E.; CHINOU, I. Chemical analysis of Greek pollen: antioxidant, antimicrobial and proteasome activation properties. Chemistry Central Journal, v. 5, n. 1, p. 33, 2011. http://dx.doi.org/10.1186/1752-153X-5-33. PMid:21699688. 
Phytochemical analysis and botanical origin of Apis mellifera bee pollen from the municipality of Canavieiras, Bahia State, Brazil

Negri, G. et al.

GROSSO, C.; VALENTÃO, P.; FERRERES, F.; ANDRADE, P. The use of flavonoids in central nervous system disorders. Current Medicinal Chemistry, v. 20, n. 37, p. 4694-4719, 2013.

HANDRICK, V.; VOGT, T.; FROLOV, A. Profiling of hydroxycinnamic acid amides in Arabidopsis thaliana pollen by tandem mass spectrometry. Analytical Bioanalytical Chemistry, v. 398, n. 7-8, p. 2789-2801, 2010. http://dx.doi.org/10.1007/s00216-0104129-2. PMid:20827470.

HUCK, W. C. Advances of infrared spectroscopy in natural product research. Phytochemistry Letters, v. 11, n. 2, p. 384-393, 2015. http://dx.doi.org/10.1016/j.phytol.2014.10.026.

KAFFARNIK, S.; PREUSS, S.; VETTER, W. Direct determination of flavor relevant and further branched-chain fatty acids from sheep subcutaneous adipose tissue by gas chromatography with mass spectrometry. Journal of Chromatography A, v. 1350, n. 1, p. 92-101, 2014. http://dx.doi.org/10.1016/j.chroma.2014.05.034

KHALLOUKI, F.; HAUBNER, R.; RICARTE, I.; ERBEN, G.; KLIKA, K.; ULRICH, C. M.; OWEN, R. W.; ULRICH, C.M.; OWEN, R. W. Identification of polyphenolic compounds in the flesh of Argan (Morocco) fruits. Food Chemistry, v. 179, n. 1, p. 191-198, 2015. http://dx.doi.org/10.1016/j.foodchem.2015.01.103. PMid:25722154.

KOMOSINSKA-VASSEV, K.; OLCZYK, P.; KAFMIERCZAK, J.; MENCNER, L.; OLCZYK, K. Review article bee pollen: chemical composition and therapeutic application. Evidence Based Complementary Alternative Medicine, v. 2015, p. 1-6, 2015. Article ID 297425. http://dx.doi.org/10.1155/2015/297425.

KUMAR, S.; PANDEY, A. K. Chemistry and biological activities of flavonoids: an overview. Scientific World Journal, v. 2013, p. 1-16, 2013. Article ID 162750. http://dx. doi.org/10.1155/2013/162750.

LIOLIOS, V.; TANANAKI, C.; DIMOU, M.; KANELIS, D.; GORAS, G.; KARAZAFIRIS, E.; THRASYVOULOU, A. Ranking pollen from bee plants according to their protein contribution to honey bees. Journal of Apicultural Research, v. 54, n. 5, p. 582-592, 2015. http://dx.doi.org/10.1080/00218839.2016.1173353.

LORENZI, H. Árvores brasileiras: manual de identificação e cultivo de plantas arbóreas do Brasil. Nova Odessa: Instituto Plantarum, 2002.

LOUVEAUX, J.; MAURIZIO, A.; VORWOHL, G. Methods of melissopalynology. Bee World, v. 59, n. 2, p. 139-157, 1978. http://dx.doi.org/10.1080/0005772X.1978.11097714.

LV, H.; WANG, X.; HE, Y.; WANG, H.; SUO, Y. Identification and quantification of flavonoid aglycones in rape bee pollen from Qinghai-Tibetan Plateau by HPLC-DAD-APCI/MS. Journal of Food Composition and Analysis, v. 38, n. 1, p. 49-54, 2015. http://dx.doi.org/10.1016/j.jfca.2014.10.011.

MARKHAM, K.; CAMPOS, M. G. R. 7- and 8-O-Methylherbacetin3-O-sophoroside from bee pollens and some sctruture/activity observations. Phytochemistry, v. 43, n. 4, p. 763-767, 1996. http://dx.doi.org/10.1016/0031-9422(96)00286-5.
MARTINS, M. C. T.; MORGANO, M. A.; VICENTE, E.; BAGGIO, S. R.; RODRIGUEZ-AMAYC, D. B. Physicochemical composition of bee pollen from eleven Brazilian states. Journal of Apicultural Science, v. 55, n. 2, p. 107-116, 2011.

MIHAJLOVIC, L.; RADOSAVLJEVIC, J.; BURAZER, L.; SMILJANIC, K.; CIRKOVIC VELICKOVIC, T. Composition of polyphenol and polyamide compounds in common ragweed (Ambrosia artemisiifolia L.) pollen and sub-pollen particles. Phytochemistry, v. 109, n. 1, p. 125-132, 2015. http://dx.doi.org/10.1016/j. phytochem.2014.10.022. PMid:25468540.

MINOIS, N. Molecular basis of the "anti-aging" effect of spermidine and other natural polyamides: a mini-review. Geronthology, v. 60, n. 4, p. 319-326, 2014. http://dx.doi.org/10.1159/000356748. PMid:24481223.

MINOIS, N.; CARMONA-GUTIERREZ, D.; MADEO, F. Polyamines in aging and disease. Aging, v. 3, n. 8, p. 716-732, 2011. http:// dx.doi.org/10.18632/aging.100361. PMid:21869457.

MINOIS, N.; ROCKENFELLER, P.; SMITH, T. K.; CARMONAGUTIERREZ, D. Spermidine feeding decreases age-related locomotor activity loss and induces changes in lipid composition. Plos One, v. 9, n. 7, p. e102435, 2014. http://dx.doi.org/10.1371/ journal.pone.0102435. PMid:25010732.

MULARCZYK-OLIWA, M.; BOMBALSKA, A.; KALISZEWSKI, M.; WŁODARSKI, M.; KOPCZYNSKI, K.; KWASNY, M.; SZPAKOWSKA, M.; TRAFNY, E. A. Comparison of fluorescence spectroscopy and FTIR in differentiation of plant pollens. Spectrochimica Acta Molecular Biomolecular Spectroscopy, v. 97, n. 2, p. 246-254, 2012. http://dx.doi.org/10.1016/j.saa.2012.05.063. PMid:22765943.

NEGRI, G.; SANTI, D.; TABACH, R. Chemical composition of hydroethanolic extracts from Siparuna guianensis, medicinal plant used as anxiolytics in Amazon region. Revista Brasileira Farmacognosia, v. 22, n. 5, p. 1024-1034, 2012. http://dx.doi. org/10.1590/S0102-695X2012005000034.

NEGRI, G.; TEIXEIRA, E. W.; ALVES, M. L.; MORETI, A. C.; OTSUK, I. P.; BORGUINI, R. G.; SALATINO, A. Hydroxycinnamic acid amide derivatives, phenolic compounds and antioxidant activities of extracts of pollen samples from Southeast Brazil. Journal Agricultural Food Chemistry, v. 59, n. 10, p. 55165522, 2011. http://dx.doi.org/10.1021/jf200602k. PMid:21500799.

OLVERA-GARCIA, V.; MARTIN DEL CAMPO, S. T.; GUTIERREZURIBE, J. A.; CARDADOR-MARTINEZ, A. GC-MS and HPLC-MS-TOF characterization of Agave atrovirens extracts: a preliminary study. Industrial Crops Products, v. 78, n. 1, p. 39-47, 2015. http:// dx.doi.org/10.1016/j.indcrop.2015.09.068.

RODRÍGUEZ-PÉREZ, C.; QUIRANTES-PINÉ, R.; AMESSISOUCHEMOUKH, N.; MADANI, K.; SEGURA-CARRETERO, A.; FERNÁNDEZ-GUTIERREZ, A. A metabolite-profiling approach allows the identification of new compounds from Pistacia lentiscus leaves. Journal Pharmaceutical Biomedical Analysis, v. 77, n. 
Phytochemical analysis and botanical origin of Apis mellifera bee pollen from the municipality of Canavieiras, Bahia State, Brazil

Negri, G. et al.

1, p. 167-174, 2013. http://dx.doi.org/10.1016/j.jpba.2013.01.026. PMid:23434494

SIMIRGIOTIS, M. J.; BÓRQUEZ, J.; SCHMEDA-HIRSCHMANN, G. Antioxidant capacity, polyphenolic content and tandem HPLC-DAD-ESI/MS profiling of phenolic compounds from the South American berries Luma apiculata and L. Chequén. Food Chemistry, v. 139, n. 1-4, p. 289-299, 2013. http://dx. doi. org/10.1016/j.foodchem.2013.01.089. PMid:23561108.

SOBOLEV, V. S.; SY, A. A.; GLOER, J. B. Spermidine and flavonoid conjugates from peanut (Arachis hypogaea) flowers. Journal Agricultural Food Chemistry, v. 56, n. 9, p. 2960-2969, 2008. http://dx.doi.org/10.1021/jf703652a. PMid:18412366.

TAO, W.; YANG, N.; DUAN, J.; WU, D.; GUO, J.; TANG, Y.; QIAN, D.; ZHU, Z. Simultaneous determination of eleven major flavonoids in the pollen of Typha angustifolia by HPLC-PDA-MS.

Phytochemical Analysis, v. 22, n. 5, p. 455-461, 2011. http:// dx.doi.org/10.1002/pca.1302. PMid:22033915.
VERGERON, P. Interprétation statistique des résultats en matière d'analyse pollinique des miels. Annales de l'Abeille, v. 7, n. 4, p. 349-364, 1964. http://dx.doi.org/10.1051/apido:19640407.

YANG, Z.; DONG, F.; BALDERMANN, S.; MURATA, A.; TU, Y.; ASAI, T.; WATANABE, N. Isolation and identification of spermidine derivatives in tea (Camellia sinensis) flowers and their distribution in floral organs. Journal of Science Food Agricultural, v. 92, n. 10, p. 2128-2132, 2012. http://dx.doi.org/10.1002/jsfa.5596. PMid:22298050.

ZHOU, J.; QI, Y.; RITHO, J.; ZHANG, Y.; ZHEN, X.; WU, L. Flavonoid glycosides as floral origin markers to discriminate of unifloral bee pollen by LC-MS/MS. Food Control, v. 57, n. 1, p. 54-61, 2015. http://dx.doi.org/10.1016/j.foodcont.2015.03.035.

ZIMMERMANN, B.; KOHLER, A. Infrared spectroscopy of pollen identifies plant species and genus as well as environmental conditions. Plos One, v. 9, p. e95417, 2014. 
Phytochemical analysis and botanical origin of Apis mellifera bee pollen from the municipality of Canavieiras, Bahia State, Brazil

Negri, G. et al.

\section{Supplementary Material}

The following online material is available for this article:

Figures 1S-48S

This material is available as part of the online article from https://www.scielo.br/bjft 


\section{Erratum}

In the article "Phytochemical analysis and botanical origin of Apis mellifera bee pollen from the municipality of Canavieiras, Bahia State, Brazil", DOI http://dx.doi.org/10.1590/1981-6723.17616, published in Brazilian Journal of Food Technology, vol. 21, 16 pp., on page $\mathbf{1}$,

where it reads:

Giuseppina Negri, Lidia Maria Ruv Carelli Barreto², Fábia Lugli Sper ${ }^{3}$, Claudemir de Carvalho³, Maria da Graça Rodrigues Campos ${ }^{4}$

It should be read:

Giuseppina Negri, Lidia Maria Ruv Carelli Barreto², Fábia Lugli Sper³, Claudemir de Carvalho³, Maria da Graça Ribeiro Campos ${ }^{4}$ 